\title{
STUDY OF PEAK EXPIRATORY FLOW RATE AMONG VEGETABLE FARMERS USING PESTICIDES IN BOYOLALI DISTRICT, CENTRAL JAVA, INDONESIA
}

\section{Manggala Sariputri $\left.{ }^{1 *}\right)$ Ari Probandari², Hartono ${ }^{3}$, Eti Poncorini Pamungkasari², Isna Qadrijati ${ }^{4}$}

${ }^{1}$ Master Program of Family Medicine, Sebelas Maret University, Surakarta, 57126, Indonesia ${ }^{2}$ Department of Public Health, Faculty of Medicine, Sebelas Maret University, Surakarta, 57126, Indonesia

${ }^{3}$ Department of Physiology, Faculty of Medicine, Sebelas Maret University, Surakarta, 57126, Indonesia

${ }^{4}$ Study Program of Occupational Safety and Health, Faculty of Medicine, Sebelas Maret

University, Surakarta, 57126, Indonesia

Received July 01, 2019; Accepted January 08, 2020

\begin{abstract}
Pesticides exposure affects respiratory system. The study of peak expiratory flow rate (PEFR) as a parameter of lung function changes due to limited pesticide among farmers. This crosssectional study aims to analyze factors affecting PEFR and formulate a model for predicting PEFR among 76 vegetable farmers using pesticides in Tlogolele Village, Boyolali Regency. Data were collected through questionnaire-based interview and clinical examination. PEFR test was conducted using a peak flow meter while cholinesterase level was investigated using Deutsche Gessellschaftfur Klinische Chemie method. The data were analyzed using unpaired T-test and Pearson test continued by multivariate regression models. The examination showed $75 \%$ of subjects had abnormal PEFR. Cholinesterase, body mass index, smoking habits, personal protective equipment usage, pesticide dosage, length of work per day, and last time of spraying did not show a significant correlation with PEFR. On the other hand, age, height, weight, frequency of spraying, and spraying duration showed a significant correlation with PEFR and a prediction equation for PEFR model was obtained as $\mathrm{R}^{2}=0.268(\mathrm{p}<0.001)$. The developed model will be useful for early detection of abnormal lung function.
\end{abstract}

Keywords: occupational health; peak expiratory flow rate; pesticide exposure.

\section{INTRODUCTION}

Pesticide exposure is still a health problem throughout the world especially in developing countries. In the past 10 years, there had not been any complete statistical data on morbidity and mortality due to pesticide poisoning globally (Calvert et al., 2010; WHO, 2008). The World Health Organization (WHO) estimates that there are around 5 million cases of accidental pesticide poisoning and 20,000 deaths per year due to pesticide poisoning. The incidence of acute pesticide poisoning in the workplace is 1.17 per 100,000 workers and insecticides are the most common cause (49\%) of all pesticides. The incidence of pesticide poisoning is higher in agricultural sector compared to non-agricultural sector (Calvert et al., 2004; UN, 2017). The level of pesticide poisoning is influenced by various factors including internal and external factors. Internal factors include age, sex, and nutritional status. External factors are pesticide dosage, frequency of spraying, length of work per day, length of service, time of the last spraying, habitual use of personal protective equipment 
(PPE), spraying time, and environmental temperature (Djojosumarto P, 2008; Eddleston, 2015; Wudianto, 2007).

Exposure to pesticides in workplace occurs in all agricultural processes such as mixing, spraying, planting, harvesting, weighing, product packaging, and washing agricultural equipment. Spraying is the most important process in pest control (Sapbamrer $\&$ Nata, 2014). During the process of pesticide spraying, steam and aerosol droplets from the pesticide solution can enter the body through inhalation. Inhalation of pesticides can cause damage to the nose, throat, and lung tissue because of which lung function changes and the risk of respiratory symptoms and diseases increases (Sapbamrer et al., 2019).

Several previous studies have reported an association between exposure to pesticides at work and respiratory disorders such as chronic obstructive pulmonary disease, asthma and chronic bronchitis (Alif et al., 2017; Hoppin et al., 2009; Lytras et al., 2018). Occupational exposure can also induce or exacerbate asthma. Variability of asthma control is worse during periods at work than away from work (Quirce et al., 2013; Suhadi et al., 2018). Several other studies report that the prevalence of respiratory symptoms is associated with pesticides (Buralli et al., 2018; Mathew et al., 2015). Evidence of decreased lung function tests associated with pesticide exposure among agricultural workers has also been reported in several studies (Chakraborty et al., 2009; Sapbamrer et al., 2019). These studies support evidence that exposure to pesticides has an adverse effect on the respiratory system.

Lung function can be assessed through several methods one of which is by peak expiratory flow rate (PEFR). PEFR measures the maximum expiratory speed that can be achieved by someone and is expressed in liters per minute $(\mathrm{L} / \mathrm{min})$ or liters per second $(\mathrm{L} / \mathrm{sec})$. PEFR mainly reflects the flow in large airways and depends on the conscious effort and muscle strength of the individual. PEFR values are obtained by spirometry test or using a simpler tool namely peak expiratory flow (PEF) meter. PEFR examination with PEF meter is easier, simpler, cheaper, and quantitative (Ismaila et al., 2015; Mridha et al., 2011; Thorat et al., 2017). Differences in PEFR values among populations can be caused by geographical factors, types of environmental and occupational exposure, socioeconomic status, and ethnic differences that affect variations between individuals. Therefore, PEFR prediction model will be more appropriate if each region has its own values (Nayak et al., 2016; Prasad et al., 2006). Research on the correlation between pesticide exposure and PEFR is still very limited. To the best of our knowledge, there is only one study about the correlation between blood cholinesterase activity and PEFR in Indonesia in which the subject of that study was potato farmers with chronic exposure to organophosphate pesticides. The results indicate a significant positive correlation of a low degree of blood acetylcholinesterase activity with PEFR (Luthfanto et al., 2014).

Boyolali Regency is one of regions in Central Java of which the economy relies on agricultural sector. For the last five years, 50 percent of Boyolali's population has worked in agricultural sector. Its best agricultural products include tobacco and vegetables. Selo District is a vegetable producing center in Boyolali (BPS Boyolali, 2018a). Tlogolele is one of villages in Selo District with main commodities of chilies, tomatoes and mustard greens.

Some areas of Tlogolele have agricultural activities throughout the year due to the availability of water in the area (BPS Boyolali, 2018). Based on research on pesticide poisoning in Selo District, data obtained from pesticide poisoning reached $73.9 \%$. Factors related to pesticide poisoning are years of pesticide application, personal protective equipment (PPE), and frequency of spraying (Harriyani, 2016). Based on the explanation above, this study aims to determine PEFR, analyze the factors that affect PEFR and formulate a model of PEFR predictors towards vegetable farmers using pesticides in Tlogolele Village, Boyolali Regency. 


\section{METHODS}

This study is an observational research applying cross-sectional design with the study permit No. 070/412/VI/39/2019 issued by Kantor Kesatuan Bangsa dan Politik Kabupaten Boyolali (The Office of Political and National Unity of Boyolali Regency). The study protocol was approved by the Ethics Commission of Medical Faculty, Sebelas Maret University with the Ethical Clearance No. 261/UN27.06/KEPK/EC/2019. This study was part of the study and development of implemented model for health service of work related illness in national health coverage era for holistic and integrated occupational health efforts.

\section{Selection of Subjects}

Samples were taken from farmers who used chemical pesticides in Tlogolele Village, Selo District, Boyolali Regency who met the inclusion and exclusion criteria. Inclusion criteria included staying for minimum one year in Selo District of Boyolali Regency, men aged between 20-65 years, carrying out pesticide spraying activities for at least one year, and willing to be the subject of research by signing informed consent. Exclusion criteria included a history and symptoms of lung and liver dysfunction, signs of malignancy, a history of alcoholic drinking habits, and the use of cholinesterase inhibitors. The sampling technique applied consecutive sampling.

\section{Procedures}

The independent variable of the study is blood cholinesterase activity investigated in Laboratory of Health and Medical Devices Testing (Balai Laboratorium Kesehatan dan Pengujian Alat Kesehatani) using Deutsche Gessellschaftfur Klinische Chemie (DGKC) method whereas the dependent variable is peak expiratory flow rate measured by Philips Respironics PesonalBest ${ }^{\circledR}$ peak flow meter. Additional variables were generated by questionnaire-based interview and clinical examination for demographic characteristics, history of pesticides application, and anthropometric variables. Data collection was completed at village hall of Tlogolele. The data collectors consisted of the interviewer and the note documenter who guided the respondents in answering the questionnaires. All data collectors were trained for their reliability in understanding the questions and the respondents' answers before the interview.

\section{Data Analysis}

Categorical data including smoking habits, personal protective equipment usage, and pesticide dosage were analyzed using unpaired T-test. Meanwhile, the ratio data of cholinesterase, age, height, weight, body mass index, frequency of spraying, the length of work per day, spraying duration, and last time of spraying were analyzed for their distributions followed by Pearson or Spearman test depending on the normal distribution of the data. Multivariate regression models were performed on the data. All the statistical analyses were performed using IBM SPSS software version 22 (IBM Corp., Chicago, USA). p-values $<0.05$ were considered significant.

\section{RESULTS AND DISCUSSION}

The research subjects consisted of 76 farmers who used chemical pesticides. Demographic and physical characteristics, history of pesticide application, PEFR, and blood cholinesterase are shown in Table 1. The mean age of the study sample was $41.86 \pm$ 10.18. Most of these farmers were graduated from elementary school for as many as 59 $(77.6 \%)$. The highest income was less than Indonesian rupiah (IDR) 1,000,000 which were occupied by 50 subjects $(65.8 \%)$. Normal nutritional status was $50(65.8 \%)$ with the mean of body mass index (BMI) of 22.09 \pm 2.38 $\mathrm{kg} / \mathrm{m}^{2}$. Smoking habits were performed by 60 subjects $(78.9 \%)$. The mean height of the study sample was $159.03 \pm 7.02 \mathrm{~m}$ while the mean body weight was $56.06 \pm 8.42 \mathrm{~kg}$.

Data on pesticide application in this study included the use of personal protective equipment (PPE), pesticide dosage, frequency of spraying, length of work, duration of spraying, and last time of spraying (Table 1). 
The results showed that there were only 14 subjects $(18.4 \%)$ used complete PPE. As many as 43 subjects $(56.6 \%)$ had used the dosage of pesticides according to the rules namely 1.5-2 cc/liters of solvent. The highest frequency of spraying was 2 times/week performed by 37 subjects $(48.7 \%)$. The longest working duration was 2 hours/day performed by 25 subjects $(32.9 \%)$. The longest spraying duration was 11-20 years by 34 subjects $(44.7 \%)$. The closest last time of spraying was 1-7 days for as many as 44 subjects $(57.9 \%)$.

The results of the examination in this study are 71 subjects $(93.4 \%)$ with normal cholinesterase levels and 5 subjects $(6.6 \%)$ with abnormal cholinesterase levels. The results of this study are in line with a study showing normal cholinesterase which is higher than abnormal cholinesterase (Sandra et al., 2019). An examination of cholinesterase activity is an assessment of organophosphate poisoning in workers. Decreasing blood cholinesterase activity is reduced due to the inhibition of cholinesterase enzyme activity by organophosphates. However, cholinesterase activity may not always be able to describe the level of chronic organophosphate poisoning especially at low dose exposure because there is a recovery period of cholinesterase activity after exposure. This recovery period ranges from 35-100 days after exposure (Eddleston, 2015; Ye et al., 2013).

Based on PEFR normal values guidelines by Indonesian Pneumobile Project Team in 1992 (Alsagaff et al., 1992), the PEFR examination in this study showed an abnormal result in 57 subjects $(75 \%)$. The mean PEFR value of the sample was $407.96 \pm 96.04$. These results are in line with studies that show higher abnormal lung function than normal lung function in farmers with exposure to pesticides (Luthfanto et al., 2014; Sandra et al., 2019). This study is also consistent with other studies which figure out a significant decrease in PEFR among farmers compared to the control (Priyadharshini et al., 2017). Decreased PEFR values can be a sensitive indicator in predicting the amount of airway obstruction. Pesticide aerosol drops that are sprayed in the air can get in through inhalation which causes irritation and narrowing of the airway (Sapbamrer et al., 2019). The results of these studies provide evidence on the adverse effects of exposure to pesticides on the respiratory system.

Bivariate test results (Table 2) in this study showed a significant relationship between age $(\mathrm{r}=-0,458 ; \mathrm{p}=0,000)$, height $(\mathrm{r}=0.434 ; \quad \mathrm{p}=0,000), \quad$ weight $\quad(\mathrm{r}=-0,322$; $\mathrm{p}=0.005)$, spraying frequency $\quad(\mathrm{r}=-0.279$; $\mathrm{p}=0.015)$, and spraying duration $(\mathrm{r}=-0.336$; $\mathrm{p}=0.002$ ) with PEFR. Whereas variables of blood cholinesterase, BMI, smoking habits, PPE usage, pesticide dosage, length of work, and last time of spraying did not show a significant relationship with PEFR. Negative correlation on age variable with PEFR is in line with studies conducted both in the general population and certain occupational exposures (Bhardwaj et al., 2014; Price et al., 2013). PEFR values decrease with increasing age due to degenerative changes in musculoskeletal system of the thoraco-abdominal compartment which cause a decrease in the strength of respiratory muscles. In addition, the airways also experience increasing resistance due to functional changes with age (Bhardwaj et al., 2014; Mukherjee et al., 2018).

Height shows a positive correlation with PEFR. This is in line with research conducted on both male and female populations (Garg et al., 2015). Taller people have greater chest volume. Also, airway growth and respiratory muscle effort increase with greater body height (Mukherjee et al., 2018). Analysis on weight variable with PEFR is in line with studies that show a positive correlation between body weight and PEFR (Bedi \& Dang, 2016; Kaur et al., 2013). This finding is due to respiratory tract and greater muscular expiratory effort as we gain weight (Mukherjee et al., 2018).

The spraying duration in this study shows a negative correlation with PEFR. These results are in line with a research by Fareed $e t$ al. (2013) which shows a negative correlation between duration of exposure and PEFR ( $\mathrm{r}=$ $0.41 ; \mathrm{p}<0.01)$. The duration of exposure in this study is also associated with respiratory symptoms. Research conducted by 
Chakraborty et al. (2009) also shows results that are consistent with the results of this study. In this study, spraying frequency shows a negative correlation with PEFR. To the best of our knowledge, no previous studies have analyzed the correlation between the frequency of spraying and PEFR.

Table 1. Demographic and Physical Characteristics, History of Pesticide Application, PEFR, and Blood Cholinesterase among Male Sprayers $(n=76)$

\begin{tabular}{|c|c|c|}
\hline Variable & n $(\%)$ & $\begin{array}{c}\text { Mean } \pm \text { SD or Median } \\
\text { (Min-Max) }\end{array}$ \\
\hline Age & & $41.86 \pm 10.18$ \\
\hline \multicolumn{3}{|l|}{ Education } \\
\hline No school & $2(2.6)$ & \\
\hline Graduated from elementary school & $59(77.6)$ & \\
\hline Graduated from middle school & $8(10.5)$ & \\
\hline Graduated from high school & $7(9.2)$ & \\
\hline \multicolumn{3}{|l|}{ Income } \\
\hline$<$ IDR $1,000,000$ & $50(65.8)$ & \\
\hline IDR $1,000,000-2,500,000$ & $24(31.6)$ & \\
\hline IDR $2,500,000-5,000,000$ & $2(2.6)$ & \\
\hline \multicolumn{3}{|l|}{ Smoking habit } \\
\hline Yes & $60(78.9)$ & \\
\hline No & $16(21.1)$ & \\
\hline \multicolumn{3}{|l|}{ Nutritional Status / Body Mass Index } \\
\hline Less & $4(5.3)$ & \multirow{3}{*}{$22.09 \pm 2.38$} \\
\hline Normal & $50(65.8)$ & \\
\hline More & $22(28.9)$ & \\
\hline Height $(\mathrm{cm})$ & & $159.03 \pm 7.02$ \\
\hline Weight (kg) & & $56.06 \pm 8.42$ \\
\hline \multicolumn{3}{|l|}{ Use of PPE } \\
\hline Complete & $14(18.4)$ & \\
\hline Incomplete & $62(81.6)$ & \\
\hline \multicolumn{3}{|l|}{ Pesticide Dosage } \\
\hline By the rules & $43(56.6)$ & \\
\hline Not according to rules & $33(43.4)$ & \\
\hline Spraying Frequency (times/week) & & $2(1-4)$ \\
\hline Length of Work (hours/day) & & $2(1-6)$ \\
\hline Spraying Duration (year) & & $20(1-40)$ \\
\hline Last Time of Spraying (day) & & $7(1-196)$ \\
\hline \multicolumn{3}{|l|}{ Peak Expiratory Flow Rate (L/min) } \\
\hline Normal & $19(25)$ & \multirow{2}{*}{$407.96 \pm 96.04$} \\
\hline Abnormal & $57(75)$ & \\
\hline \multicolumn{3}{|l|}{ Blood Cholinesterase (U/L) } \\
\hline Normal & $71(93.4)$ & \multirow{2}{*}{$5754.00(2534-9761)$} \\
\hline Abnormal & $5(6.6)$ & \\
\hline
\end{tabular}

Note: Mean \pm SD = mean \pm standard deviation; Median $($ Min-Max $)=$ median $($ minimum-maximum $) ;$ IDR = Indonesian rupiah; $\mathrm{PPE}=$ personal protective equipment 
Previous studies analyzed the correlation between frequency of spraying and other lung function parameters such as forced expiratory volume in one second/forced vital capacity ( $\left.\mathrm{FEV}_{1} / \mathrm{FVC}\right)$, and forced expiratory flow at 25 $75 \%$ of the pulmonary volume $\left(\mathrm{FEF}_{25-75 \%}\right)$. The results of this study indicate a negative correlation between the frequency of spraying and $\mathrm{FEV}_{1} / \mathrm{FVC}(\mathrm{r}=-0.85 ; \mathrm{p}<0.001)$ and $\mathrm{FEF}_{25}$ $75 \%$ ( $\mathrm{r}=-0.62 ; \mathrm{p}<0.001)$ (Buralli et al., 2018). Research using the cumulative exposure index in describing variable of spraying frequency and duration of exposure also shows the results that the cumulative exposure index is a predictor of $\mathrm{FEF}_{25-75 \%}$ with a value of $\mathrm{R}^{2} 50 \%$ $(\mathrm{r}=-0.254 ; \mathrm{p}=0.039)$ (Hernández et al., 2008). The level of pesticide poisoning depends on pesticide toxicity, pesticide formulation, pesticide particle size, PPE usage, duration, frequency, and intensity of exposure. Inhalation of pesticides can cause damage to the nose, throat, and lung tissue which can cause malfunction and increase the risk of respiratory symptoms and diseases (Damalas and Koutroubas, 2016; Mamane et al., 2015).

After conducting a bivariate analysis, all variables (use of PPE, pesticide dosage, spraying duration, height, cholinesterase, age, body weight, and spraying frequency) met the criteria for entry into the multivariate analysis (Table 3). With multivariate analysis of linear regression backward method, the PEFR equation is obtained as $=465.537+(-$ 3.627 xage $)+(2.389$ xweight $)+(-24.31 \mathrm{x}$ frequency of spraying) with an $\mathrm{R}^{2}=26.8 \%$. Equations consisting of age, body weight, and spraying frequency contributed $26.8 \%$ to the dependent variable (PEFR) while the remaining $73.2 \%$ was influenced by other variables. In Indonesia, a model to predict PEFR values was carried out by the Indonesian Pneumobile Project Team in 1992. However, the PEFR values in this study were obtained from the general population. The PEFR equation in this study consists of age and height factors (Alsagaff et al., 1992).

Table 2. Correlation between blood cholinesterase, demographic and physical characteristics with history of pesticide application and PEFR

\begin{tabular}{|c|c|c|c|c|}
\hline \multirow[b]{2}{*}{ Variable } & \multicolumn{4}{|c|}{ Peak Expiratory Flows (L/min) } \\
\hline & Mean \pm SD & $\begin{array}{c}\text { Mean difference } \\
(95 \% \mathrm{CI})\end{array}$ & p value & $\mathbf{r}$ \\
\hline Cholinesterase (U/L) & - & - & 0.145 & 0.169 \\
\hline Age (years) & - & - & $0.000 *$ & -0.458 \\
\hline Height $(\mathrm{cm})$ & - & - & $0.000 *$ & 0.434 \\
\hline Weight (kg) & - & - & $0.005^{*}$ & 0.322 \\
\hline BMI $\left(\mathrm{kg} / \mathrm{m}^{2}\right)$ & - & - & 0.391 & 0.1 \\
\hline \multicolumn{5}{|l|}{ Smoking habit } \\
\hline Yes & $405.67 \pm 94.85$ & $-10.90(-65.04-43.25)$ & 0.69 & - \\
\hline No & $416.56 \pm 103.13$ & & & \\
\hline \multicolumn{5}{|l|}{ Use of PPE } \\
\hline Complete & $441.79 \pm 78.58$ & $41.46(-14.73-97.66)$ & 0.146 & - \\
\hline Incomplete & $400.32 \pm 98.50$ & & & \\
\hline \multicolumn{5}{|l|}{ Pesticide dosage } \\
\hline By the rules & $423.95 \pm 94.07$ & $3683(6038050)$ & 0000 & \\
\hline $\begin{array}{l}\text { Not according to } \\
\text { rules }\end{array}$ & $387.12 \pm 95.99$ & $30.83(-0.93-80.59)$ & 0.098 & - \\
\hline $\begin{array}{l}\text { Spraying frequency } \\
\text { (times/week) }\end{array}$ & - & - & $0.015^{*}$ & -0.279 \\
\hline $\begin{array}{l}\text { Length of work } \\
\text { (hours/day) }\end{array}$ & - & - & 0.831 & 0.025 \\
\hline Spraying duration & - & - & $0.002 *$ & -0.356 \\
\hline $\begin{array}{l}\text { Last time of spraying } \\
\text { (days) }\end{array}$ & - & - & 0.400 & -0.098 \\
\hline
\end{tabular}

Note: Mean \pm SD $=$ mean \pm standard deviation; $95 \% \mathrm{CI}=95 \%$ confidence interval; $\mathrm{BMI}=$ body mass index; PPE = personal protective equipment; $* \mathrm{p}<0.05$ 
Table 3. Model for predicting PEFR of male sprayers $(n=76)$

\begin{tabular}{lcccc}
\hline \multirow{2}{*}{ Variable } & \multicolumn{2}{c}{ Unstandardized Coefficients } & Standardized Coefficients & \multirow{2}{*}{ p value } \\
\cline { 2 - 4 } & B & Standard Error & Beta & 0.000 \\
\hline Constant & 465.537 & 87.323 & & 0.000 \\
Age & -3.627 & 0.960 & -0.385 & 0.045 \\
Weight & 2.389 & 1.170 & 0.209 & 0.084 \\
Spraying frequency & -24.310 & 13.895 & -0.179 & \\
\hline
\end{tabular}

Note: $\mathrm{R}^{2}=26.8 \%$

Research on cement factory workers in Nigeria shows the results of the PEFR prediction model with the PEFR equation/year of exposure = $-69.985+3.425 x a g e+2.922 x$ height 2.473 xweight +10.9 xyear of exposure $\left(\mathrm{R}^{2}\right.$ $84.3 \%$; $\mathrm{p}<0.001$ ) (Ismaila et al., 2015). To the best of our knowledge, there is no PEFR prediction model for farmers with pesticide exposure. The PEFR prediction model is useful in initial screening for respiratory system disorders in farmers using pesticides.

PEFR is an indicator of airway obstruction that is sensitive and accurate. PEFR examination with PEF meters is easier, simpler, cheaper, and quantitative as well as noninvasive (Mridha et al., 2011; Thorat et al., 2017). PEFR prediction models for farmers using pesticides are useful in initial screening for respiratory system disorders. The results of this study strengthen the evidence of the correlation between pesticide exposure and respiratory system disorders. However, this study has several limitations. First, this research was only conducted in one region/village with a limited sample size. Second, this study was only conducted towards male farmers so that it limits the generalization of research results to the other gender. Third, other laboratory support parameters that might influence the level of cholinesterase were not examined in this study (e.g. hemoglobin, liver function tests, and malignancy markers.

\section{CONCLUSION}

The equation model to determine PEFR based on age, weight, and frequency of spraying was obtained with enough coefficients determination. This developed model will be useful in determining the PEFR of vegetable farmers as an effort to access possible medical attention. Multicentre studies with multigender and larger sample sizes are recommended to obtain PEFR predictor models.

\section{ACKNOWLEDGMENT}

We would like to thank the DirectorGeneral of Occupational Health and Sports, Indonesian Ministry of Health for the research grant to collaborate with Faculty of Medicine, Sebelas Maret University. We also are thankful to Sumardiyono, Vitri Widyaningsih, and the team for the permission to join the collaborative research and the technical support for writing this article.

\section{REFERENCES}

Alif, S.M., Dharmage, S.C., Benke, G., Dennekamp, M., Burgess, J.A., Perret, J.L., Lodge, C.J., Morrison, S., Johns, D.P., Giles, G.G., Gurrin, L.C., Thomas, P.S., Hopper, J.L., Wood-Baker, R., Thompson, B.R., Feather, I.H., Vermeulen, R., Kromhout, H., Walters, E.H., Abramson, M.J., Matheson, M.C., 2017. Occupational Exposure to Pesticides are Associated with Fixed Airflow Obstruction in Middle-Age. Thorax, 72(11), 990-997.

Alsagaff, H., Mangunnegoro, H., Amin, M., Yunus, F., Bernstein, R., Johnson, L., 1992. Nilai Normal Faal Paru Orang Indonesia pada Usia Sekolah dan Pekerja Dewasa Berdasarkan Rekomendasi American Thoracic Society (ATS) 1987. Paru, 12(4), 3-18.

Bedi, U., Dang, B., 2016. A Study of Peak Expiratory Flow Rate in Normal Healthy Children of Punjab. International Journal of Medical and Dental Sciences, 5(1), 1042-1047.

Bhardwaj, P., Poonam, K., Jha, K., Bano, M., 
2014. Effects of Age and Body Mass Index on Peak Expiratory Flow Rate in Indian Population. Indian Journal of Physiology and Pharmacology, 58(2), 166-169.

BPS Boyolali, 2018 a. Statistik Daerah Kabupaten Boyolali. Badan Pusat Statistika Kabupaten Boyolali, Boyolali.

BPS Boyolali, 2018 ${ }^{\text {b }}$ Kecamatan Selo dalam Angka 2018. Badan Pusat Statistika Kabupaten Boyolali, Boyolali.

Buralli, R.J., Ribeiro, H., Mauad, T., Amatolourenço, L.F., Silva, D.S., Remy, J., 2018. Respiratory Condition of Family Farmers Exposed to Pesticides in the State of Rio de Janeiro, Brazil. International Journal of Environmental Research and Public Health, 15(1203), 1-14.

Calvert, G., Mehler, L., Alsop, J., De Vries, A., Besbelli, N., 2010. Surveillance of Pesticide-Related Illness and Injury in Humans, in: Krieger, R. (Ed.), Hayes' Handbook of Pesticide Toxicology. Academic Press, USA, pp. 1313-1369.

Calvert, G.M., Plate, D.K., Das, R., Rosales, R., Shafey, O., Thomsen, C., Male, D., Beckman, J., Arvizu, E., Lackovic, M., 2004. Acute Occupational PesticideRelated Illness in the US, 1998 - 1999 : Surveillance Findings From the SensorPesticides Program. American Journal of Industrial Medicine, 23(45), 14-23.

Chakraborty, S., Mukherjee, S., Roychoudhury, S., Siddique, S., Lahiri, T., Ray, M.R., 2009. Chronic Exposure to Cholinesterase-Inhibiting Pesticides Adversely Affect Respiratory Health of Agricultural Workers in India. Journal of Occupational Health, 8(3), 1-27.

Damalas, C.A., Koutroubas, S.D., 2016. Farmers' Exposure to Pesticides : Toxicity Types and Ways of Prevention. Toxics, 4(1), 1-10.

Djojosumarto, P., 2008. Teknik Aplikasi Pestisida Pertanian. Kanisius, Yogyakarta.

Eddleston, M., 2015. Insecticides: Organic Phosphorus Compounds and Carbamates, in: Hoffman, R.S., Howland, M.A., Lewin, N.A., Nelson, L.S. (Eds.), Goldfrank's Toxicologic Emergencies.
McGraw-Hill, USA, pp. 2306-2331.

Fareed, M., Pathak, M.K., Bihari, V., Kamal, R., Srivastava, A.K., Kesavachandran, C.N., 2013. Adverse Respiratory Health and Hematological Alterations among Agricultural Workers Occupationally Exposed to Organophosphate Pesticides: A Cross-Sectional Study in North India. PLoS ONE, 8(7), 1-10.

Garg, R., Anand, S., Sehgal, R.K., Singh, H.P., 2015. Normative Data of Peak Expiratory Flow Rate in Healthy School Children of Ghaziabad City-A Pilot Study. National Journal of Physiology, Pharmacy and Pharmacology, 5(4), 309-312.

Harriyani, I., 2016. Faktor Risiko Keracunan Pestisida pada Petani Penyemprot Sayuran di Kecamatan Selo Kabupaten Boyolali. Universitas Gadjah Mada.

Hernández, A.F., Casado, I., Pena, G., Gil, F., Villanueva, E., Pla, A., 2008. Low Level of Exposure to Pesticides Leads to Lung Dysfunction in Occupationally Exposed Subjects. Inhalation Toxicology, 20(9), 839-849.

Hoppin, J.A., Umbach, D.M., London, S.J., Henneberger, P.K., Kullman, G.J., Coble, J., Alavanja, M.C.R., Beane Freeman, L.E., Sandler, D.P., 2009. Pesticide Use and Adult-Onset Asthma among Male Farmers in the Agricultural Health Study. European Respiratory Journal, 34(6), 1296-1303.

Ismaila, S.O., Akanbi, O.G., Olaoniye, W., 2015. Model for Predicting Peak Expiratory Flow Rate of Nigerian Workers in A Cement Factory in Itori, Ogun State, Nigeria. International Journal of Occupational Safety and Ergonomics, 21(4), 547-550.

Kaur, H., Singh, J., Makkar, M., Singh, K., Garg, R., 2013. Variations in The Peak Expiratory Flow Rate with Various Factors in A Population of Healthy Women of The Malwa Region of Punjab, India. Journal of Clinical and Diagnostic Research, 7(6), 1000-1003.

Luthfanto, H., Indraswari, D., Adyaksa, G., 2014. Hubungan antara Aktivitas Asetilkolinesterase Darah dan Arus 
Puncak Ekspirasi Petani Kentang dengan Paparan Kronik Pestisida Organofosfat. Universitas Dipone goro Semarang.

Lytras, T., Kogevinas, M., Kromhout, H., Carsin, A.E., Antó, J.M., Bentouhami, H., Weyler, J., Heinrich, J., Nowak, D., Urrutia, I., Martinez-Moratalla, J., Gullón, J.A., Pereira-Vega, A., Raherison-Semjen, C., Pin, I., Demoly, P., Leynaert, B., Villani, S., Gislason, T., Svanes, C., Holm, M., Forsberg, B., Norbäck, D., Mehta, A.J., Probst-Hensch, N., Benke, G., Jogi, R., Torén, K., Sigsgaard, T., Schlünssen, V., Olivieri, M., Blanc, P.D., Vermeulen, R., Garcia-Aymerich, J., Jarvis, D., Zock, J.P., 2018. Occupational Exposures and 20-Year Incidence of COPD: The European Community Respiratory Health Survey. Thorax, 1-8.

Mamane, A., Baldi, I., Tessier, J., Raherison, C., Bouvier, G., 2015. Occupational Exposure to Pesticides and Respiratory Health. European Respiratory Review, 24(136), 306-319.

Mathew, P., Jose, A., Alex, R., Mohan, V., 2015. Chronic Pesticide Exposure: Health Effects Among Pesticide Sprayers in Southern India. Indian Journal of Occupational and Environmental Medicine, 19(2), 95-101.

Mridha, M.A.-A., Amin, M.R., Kabir, A.L., 2011. Peak Expiratory Flow Rate (PEFR)A Simple Ventilatory Lung Function Test. Journal of Shaheed Suhrawardy Medical College, 3(2), 44-47.

Mukherjee, S., Banerjee, G., Mahapatra, A.B.S., 2018. Peak Expiratory Flow Rate Changes with Relevant Variables in A Population of Eastern India. Indian Journal of Physiology and Pharmacology, 62(3), 372-379.

Nayak, P.K., Satpathy, S., Manjareeka, M., Samanta, P., Mishra, J., Pradhan, B.B., 2016. Prediction Models for Peak Expiratory Flow Rate in Indian Population Aged 18-25 Years. National Journal of Physiology, Pharmacy and Pharmacology, 6(3), 200-204.

Prasad, R., Verma, S.K., Agrawal, G.G., Mathur, N., 2006. Prediction Model for
Peak Expiratory Flow in North Indian population. The Indian journal of chest diseases \& allied sciences, 48(2), 103106.

Price, J.P.K., Arthur, N., Macstephen, A.O., 2013. Correlation between Body Mass Index and Peak Expiratory Flow Rate of an Indigenous Nigerian Population in the Niger Delta Region. Research Journal of Recent Sciences, 2(2), 28-32.

Priyadharshini, U.K., Latha, R., Kavitha, U., Nirmala, N., 2017. Effects of organophosphorus pesticides on cardiorespiratory parameters among the farmers. Journal of Clinical and Diagnostic Research, 11(9), CC01-CC04. Quirce, S., Muñoz, X., Urrutia, I., Pérez-Camo, I., Sabadell, C., Domínguez-Ortega, J., Barranco, P., Plaza, V., 2013. Changes in the Asthma Control Test Score in Patients with Work-Related Asthma. Journal of Investigational Allergology and Clinical Immunology, 23(4), 284-285.

Sandra, P.S.M., Sofiana, K.D., Sutejo, I.R., 2019. Correlation of Cholinesterase Levels to Lung Function in Farmer Exposed by Organophosphate Pesticides in Sukorambi Village, Jember Regency. Journal of Agromedicine and Medical Sciences, 5(2), 35.

Sapbamrer, R., Nata, S., 2014. Health Symptoms Related to Pesticide Exposure and Agricultural Tasks among Rice Farmers from Northern Thailand. Environmental Health Preventive Medicine, 19, 12-20.

Sapbamrer, R., Thongtip, S., Khacha-ananda, S., Sittitoon, N., Wunnapuk, K., 2019. Changes in Lung Function and Respiratory Symptoms during Pesticide Spraying Season among Male Sprayers. Archives of Environmental and Occupational Health, 0(0), 1-10.

Suhadi, R., Fenty, Virginia, D.M., Setiawan, C.H., 2018. The Effect of Health Insurance on Asthma Control in Respondents with Asthma in Yogyakarta, Indonesia. Jurnal Farmasi Sains dan Komunitas, 15(2), 62-67.

Thorat, Y.T., Salvi, S.S., Kodgule, R.R., 2017. 
Peak Flow Meter with A Questionnaire and Mini-Spirometer to Help Detect Asthma and COPD in Real-Life Clinical Practice: A Cross-Sectional Study. Primary Care Respiratory Medicine, 27(1), 1-7.

UN, 2017. Report of the Special Rapporteur on the Right to Food. United Nations.

WHO, 2008. Clinical Management of Acute Pesticide Intoxication: Prevention of
Suicidal Behaviours. World Health Organization, Geneva.

Wudianto, R., 2007. Petunjuk Penggunaan Pestisida. Penebar Swadaya, Jakarta.

Ye, M., Beach, J., Martin, J.W., Senthilselvan, A., 2013. Occupational Pesticide Exposures and Respiratory Health. International Journal of Environmental Research and Public Health, 10, 64426471. 